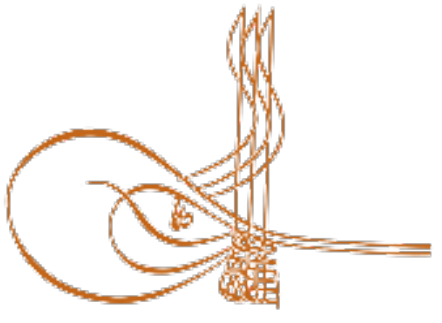

www.turkishstudies.net/language
Turkish Studies - Language and Literature

eISSN: $2667-5641$

Research Article / Araştırma Makalesi

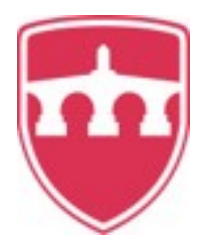

INTERNATIONAL

BALKAN

UNIVERSITY

Sponsored by IBU

\title{
Şeyhülislâm Yahyâ Divanında Fahriye ve Tevazu
}

\author{
Fahriye and Humility in Şeyhülislâm Yahyâ Divan
}

\author{
Bahanur Özkan Bahar ${ }^{*}$
}

\begin{abstract}
It is one of the basic needs of mankind that think about himself, make evaluations, make inferences and as a result appreciate, like and criticize himself. It is usual for the poet this need, because his world of emotion is much richer and more intense than an ordinary person. It is possible to see the poets' manifestations of these analyzes about themselves in their works. It is easier to identify these manifestations in Divan poems than other period poems. Because especially it is allowed and even encouraged by tradition to make ' fahriye, poets have been able to boast about themselves without hesitation.In Divan poetry, the aspect of the fahriye encouraged by the tradition is shaped by the tradition, which is related to the poet's pencil, verse, prose and talent. Although these topics are generally mentioned in Divan poetry, it is possible to come across more personal boasting reasons. Although there are relatively few samples vice versa fahriye, the opposite of the poet's humility is a situation that can be encountered in Divan poetry. In this study, one of the important representatives of 17th Century Divan Poetry, Şeyhülislam Yahya Divan is discussed. Fahriye and humility couplets were studied in the poet's Divan and as a result both humility and fahriye couplets were seen in many samples. Another subject that attracts attention in these samples is that both fahriye and humility couplets form various associations of meaning, I mean they are used in specific contexts. These meaning associations are classified and evaluated with sample couplets.
\end{abstract}

Structured Abstract: In the tradition of Divan poetry that has been going on for centuries, fahriye was one of the common elements in their poems for almost all poets. Fahriye, which means bragging with himself, was used so much by the poets that it was in the form of ode verse has been the name of a department. Although when Fahriye was said, it comes to mind ode, the poets do Fahriye

wherever possible, they were found to be Fahriye. Divan poets who like to brag about themselves, made Fahriye around certain concepts as a feature of the tradition. Verse, prose, word, pen are the general qualities that the poet boasts of himself that it is different from boasting an ordinary person with himself. While the poet was doing Fahriye, they compare themselves to the poets to be considered well known and master in the tradition. In this comparison, poet is superior to the poets who are contemporary with him, even the poets before him.

Divan poet, who does not fall behind from doing Fahriye at every opportunity he finds, it also remarkably doesn't hesitate to show humility. But, the poet's poems in humility are generally that the position

\footnotetext{
* Dr. Öğr. Üyesi, Mehmet Akif Ersoy Üniversitesi, Fen-Edebiyat Fakültesi, Eski Türk Edebiyatı Assist, Prof., Mehmet Akif Ersoy University, Faculty of Science and Litreture, Old Turkish Litreture ORCID 0000-0002-1574-2694

bahanurozkan@gmail.com
}

Cite as/ Atıf: Özkan Bahar, B. (2020). Seyhülislâm Yahyâ divanında fahriye ve tevazu- Turkish Studies - Language, 15(1), 325-340. https://dx.doi.org/10.29228/TurkishStudies.40203

Received/Geliș: 17 December/Aralık 2019 
of against God with religious content such as tawhid and münacat or related the position of against state person he wrote ode. Apart from these, he is also extremely modest in the face of his loved one. Poet never hesitates to look down on himself opposite his lover, to beg for love, because this situation proves that his love how big it is. Again there is no way to find a meeting to lover; doesn't indulge the lover easily; the poet is a lover that has difficulties; is one of the reasons that push the poet to be modest.

Şeyhülislâm Yahyâ Divan which is the subject of the study is extremely rich in terms of Fahriye and modesty examples. The poet, who is in the classical line of Divan poetry, within this framework, both he brought all his characteristics in tradition to his poetry and he has a place that brought to this poem with his original style. Considered a master both in his time and at all times Şeyhülislâm Yahyâ, in his poetry, he didn't hesitate from making fahriye and show humility when it comes to his place. He had very good expressions in both valleys. He has captured beautiful phrases that can be called posy in his poems.

The rules, structure, language, common meanings of the Divan poetry and the same verbal arts, its use for centuries is one of the biggest criticisms towards this literary tradition by the poets. A large part of these criticisms have been completed after the life of the Divan literature tradition. However, especially after the 16 th century, poets felt the need to say different things and pursued the original meanings. The tradition poet, who could not make huge changes in the form of verse, meter or arts, tried to reveal his difference with meaning.

Şeyhülislâm Yahya is one of the poets who searched and found originality in meaning and was proud of this. Fahriye which generally thought to be in the odes, in Şeyhülislâm Yahyâ,it is seen that it has spread to the whole of the poet's divan, altough it is also in odes. It was observed that fahriye couplets in the odes do not come one after another in the form of a section and it was used in a scattered way.

The poet used similar expressions while boasting his poems, as in other poets. The expressions of his poem of praise he used to define are new poetry, the secret of love, the hearten, unheard of, blessed, heart-pleasing, rose pearl, heartfelt, ore, new bride, morning wind, stream, fire. When defining his own poetry, he included statements such as unique, magnificient, master, good-spoken. The poet has right self-confidence in his poetry and words which he brags.

It is determined that the subject of the fahriye is generally in the context of poetry and poetry, also another boast is the claim of love. It appears as a feature that this is again a Divan tradition. The poet is unrivaled in love and in this science he brags with himself in study all of sciences. It has been observed that one of the couplets he made fahriye is the subject is generosity.

The first determination to be made about couplets in which the poet shows humility compared to fahriye couplets is much less in number. In his Divan, while the number of couplets he made fahriye was forty-nine, this number dropped to nine couplets when the subject was humility. Apart from the poet's fahriye and humility couplets, there are couplets that he both makes fahriye and humility, these couplets number is four.

However, the fahriye couplets made by the poet can be dealt with in seven different headings, this number was limited to three titles in humility. The reason for this difference is that examples in humility couplets are much less than the fahriye couplets.

In the title of humility, the poet, due to the position of his lover, because of their superiority in reputation, he advised humility. He advises that in a few modesty couplets other than these are necessary to be generally no-named, untitled and anonymous.

While the divan of Şeyhülislâm Yahyâ was examined, both in the poet's fahriye couplets and humility couplets, it is seen that he doesn't go far from the Divan poetry tradition. Poet's both fahriye couplets and humility couplets are in the same line with tradition. Poet who could not get out apart from these subjects, he is very competent and original in terms of power of expression. This is literally the tradition's expectation from the poet. Based on all this, the great poet of the 17th century without going out of the classical meanings and frame of Şeyhülislâm Yahyâ's Divan poet is one of the poets who managed to be different with his style.

Key Words : Divan Poem, Şeyhülislâm Yahyâ, Fahriye, Humility, Divan.

Öz: İnsanoğlunun kendisi ile ilgili düşünmesi, değerlendirmeler yapması, çıkarımlarda bulunması ve neticesinde kendisini takdir etmesi, beğenmesi, eleştirmesi insan olmanın temel gereksinimlerinden birisidir. Duygu dünyası sıradan bir insana göre çok daha zengin ve yoğun olan şairin bu gereksinimi daha derinden hissetmesi olağandır. Şairlerin kendileri ile ilgili bu tahlillerinin tezahürlerini eserlerinde görmek mümkündür. Divan şiirlerinde bu tezahürleri tespit etmek diğer dönem şiirlerine göre daha kolaydır. Çünkü özellikle "fahriye" yapmaya gelenek tarafından imkân verilmesi ve hatta teşvik edilmesi, şairlerin kendileri ile ilgili 
çekincesiz olarak övünmelerine olanak sağlamıştır. Divan şiirinde geleneğin teşvik ettiği fahriyenin yönü yine gelenek tarafından şekillendirilmiştir ki o da şairin, kalemi, nazmı, nesri, yeteneği ile ilgili olmasıdır. Genellikle Divan şiirinde, fahredilen konu başlıkları bunlar olsa da daha kişisel övünme sebeplerine de rastlamak mümkündür. Fahriyeye nispeten daha az örneği olsa da tam aksi yani şairin tevazu göstermesi de Divan şiir geleneğinde karşılaşılabilen bir durumdur. Çalışmada 17. yüzyıl Divan şiirinin önemli temsilcilerinden biri olan Şeyhülislâm Yahyâ divanı ele alınmıştır. Şairin, divanındaki fahriye ve tevazu beyitleri incelenmiş ve neticesinde hem tevazu hem de fahriye beyitlerinin çokça örneği olduğu görülmüştür. Bu örneklerde dikkat çeken bir diğer mevzu ise gerek fahriye gerekse tevazu beyitlerinin çeşitli anlam birliktelikleri oluşturdukları yani belirli bağlamlarda kullanıldıkları tespit edilmiştir. Bu anlam birliktelikleri tasnif edilip örnek beyitleriyle birlikte değerlendirilmeye çalışılmıştır.

Anahtar Kelimeler: Divan Şiiri, Fahriye, Tevazu, Şeyhülislâm Yahyâ, Divan.

\section{Giriş}

Divan şiirinde gazelden sonra şairlerin en çok rağbet ettikleri nazım şekillerinden birisi de kasidedir. Bir kişiyi övmek amaçlı yazılan kasidelerde nesib, methiye, tegazzül, fahriye ve duadan müteşekkil beş esas kısım bulunur. Başlarda fahriyenin ihmal edildiği kasideler olsa da zamanla kasidenin vazgeçilmez bir bölüml olmuştur. Fahriye, kasidede şairin kendisini övdüğü bölüme verilen addır. Övgü genellikle şairin, şiiri, şiir yazmadaki yeteneği ile alakalıdır. Şair kendisini överken daha çok şiirdeki kudreti, yeteneği, nazmı, nesri, kalemi, sözde kendisine eş ve benzer olamayacağ 1 gibi özelliklerini dile getirir ve bunu yaparken kendisini belli şahsiyetlerle kıyaslar (İsen, 2002; 5).

Fahriye denilince genellikle kasidenin bir bölümü akla gelse de şairlerin fahriye yaptıkları tek nazım şekli kaside değildir. Kasidelerin dışında şairlerin gazellerinde, mesnevilerinde ve diğer nazım şekillerinde hatta kasidelerin dua kısımlarında da fahriye yaptıkları görülmektedir. Cem Dilçin "Divan Şiiri ve Şairleri Üzerine İncelemeler" adlı eserinde "temeddüh" teriminin açıklarken şairlerin makta beyitlerinde çoğu zaman fahriye yaptıklarını yani şiirleri ve şairlikleri ile övündüklerini belirtmiştir (Dilçin, 2011; 20).

Şairlerin fahriye yapmasında muhtelif sebepler bulunmaktadır. Övülme, takdir edilme, beğenilme gibi insani bir ihtiyacın, duygu dünyaları daha yoğun olan şairlerde olması kaçınılmazdır. Divan edebiyatı geleneğinde takdir edilen, beğenilen şairlerin maddi-manevi birçok iltifata mazhar oldukları da bilinmektedir. Ancak şairin istediği maddi ve manevi alakayı görebilmesi, kendisindeki cevheri gösterebilmesiyle de doğru orantılıdır. Şair bu amaçla kendi kadrini bildirme işini kendisi üstlenir ve şiirlerinde kendisi ile övünmesinin en önemli sebeplerinden birisi budur. Bununla başta padişah, saray erkânı ve sanatçıyı destekleyebilecek çevrelerin dikkatini çekmeyi amaçlar.

Bir diğer önemli sebep ise Divan şiirinde, şairin doğrudan şiirin içinde yer almaması ve kendisini şiirinden soyutlamasıdır. Gelenekteki bu soyutlanma durumu şairin kendisi hakkında tafsilatlı bilgi vermesine mani olur. Şiirlerinde fiziksel özelliklerini, mal varlığını, makamını ya da övünmek istediği diğer vasıflarını anlatamayan şair bu ihtiyacını fahriyelerinde kalemine yönelterek gidermiştir. Çünkü şairin kendisinden belirgin bir şekilde bahsetmesine imkân vermeyen gelenek; şiirdeki yeteneği ile övünmesine olanak tanımakta hatta şairler arasındaki rekabetten dolayı teşvik etmektedir.

Şair, fahriye yaparken kendisini övdügü gibi kendisinden ve şiirinden yola çıkarak aslında şiirde ya da şairde olması gereken vasıfları da sıralar. Yani fahriye yaparken aslında ideal bir şair algıs1 oluşturmaya çalışırlar (Yazar-Uslu, 2016; 489). Oluşturduğu bu şair portresinde şairde ve şiirde, olması ve olmaması gerekenleri sıralar. Bu yolla bizzat kendisinin şaire ve şiire bakış açısını da aktarmış olur. 
Yukarıda sıraladığımız sebeplerden ortaya çıkan ancak zamanla kendisi de fahriye yapmaya sebep olan bir diğer özellik ise şairin gerek çağdaşları gerekse kendisinden önceki asırların büyük şairleri ile bir rekabet halinde olmasıdır. Bu rekabetteki yerini, farkını, önemini ve dahi gerek çağdaşı gerekse kendinden önceki büyük şairlerden farksız, hatta ilerde olduğunu ispat amaçlı fahriyeler söyler.

Tüm bu gelişim ve olgunlaşma serüveninin neticesinde şairin şiirdeki gücünü ispat çabas1 içerisinde olması Divan şiiri geleneğinin bir hususiyeti haline gelmiştir. Şekil ve muhtevaya ait unsurların hemen hepsinin gelenek tarafından tayin edildiği bu şiirde, şair, diğer şairlerden farklı olabilmek için orijinal anlam ve hayallerin peşindedir. Benzer ifadeler, aynı şeyi aynı şeklide ifade eden sanatlar henüz 16. yüzyılda dikkat çekmiş ve farklı olmaya çalışan şairler tarafından kaçınılır olmuştur.

Durum değerlendirmesi yapan, orijinalliği yakalama çalışan şair, yakaladığını düşündüğü zaman da bunun ispatına da çalışmıştır. Yukarıda da belirtildiği gibi şairin kıymetini bildirme işi de kendisine düşmektedir. Şairler, aranılan, peşine düşülen bu tarz ifadeleri tanımlamak için de benzer kalıpları kullanmışlardır. Bunlardan en yağın olarak kullanılanlar şunlardır: Bikr-i fikr, bikr-i ma'nâ, dil-i pâk, endîşe, hayâl, himmet-i fikr, ince hayâl, kilk-i ter, lafz-1 pâk, ma'nâ-yı güzîde, nazm-1 pâk, nazm-1 ter, nükte-bâr kalem, nükte-i nazm, rengîn fikr, rengîn söz, rengîn ü muhayyel lafz, sühân-1 pâk, şi'r-i pâk, şi'r-i ter, tâze eş’âr, tâze sahîfe-i şiir, tuhfe-i mazmûn ve zebân-1 tâze (İsen-Durmuş; 2007; 109).

Divan edebiyatına, diline, benzer mazmunların kullanılmasına yapılan eleştirilerin hemen hepsi bu geleneğin ömrünü tamamlamasından sonra başlamıştır. Bununla beraber bu edebi gelenek yaşatıldığ anlamda tenkit etmeseler de durum değerlendirmesi yapabilme kudretine de vakıftılar. Yani birbirini tekrar eden terkipler, tanımlar, sanatlardan uzaklaşma ve yeni, orijinal, benzersiz ifadeler bulma çabasına girişmişlerdir. Bu durum değerlendirmesi neticesinde şiirlerin orijinal anlamlar ihtiva ettiğini ifade eden yukarıda zikredilen tanımlar ortaya çıkmıştır. Şairlerin bu tarz kullanımların peşine düşmesi özellikle 16. yüzyılda başlamış olup sonrası Divan şiirinde takip edilebilmektedir.

17. yüzyılın en önemli şairlerinden olan Nef'̂̂, fahriye denilince de akla gelen ilk isimlerdendir. Öyle ki divanına "Sözüm" redifli bir na'tla başlamış ve burada sözüm diyerek kastettiği şiirinin özelliklerini sıralamıştır. Bu meşhur kasideye kendisini överek başlayan şair manzumenin büyük kısmını memduhuna değil kendisini övmeye ayırmıştır. Hem divanına hem de kaside nazım şeklinde yazılmış bu manzumeye kendini överek başlayan şairin bu hususta orijinalliği yakaladığı söylenebilir.

Şiirini övme, takdir etme işini kimselere bırakmayan şair muhtelif beyitlerde üslubunun özelliklerini şöyle tasvir etmiştir: "Yeni, tâze, pâkize, bî-bedel, nev edâ, fikr-i bikr, muciz dem, nâzik sühan" (Akkuş, 1993;8).

Şair üslubundaki benzersizliği överken kendisini daima büyük şairlerle kıyaslar ve şiirinin onların gerisinde olmadığını iddia eder. Bu kıyaslama beyitlerinde şairler, İran ve Arap edebiyatındaki büyük şairlerin isimlerini zikrederek şiirlerinin başarısını ispata çalışır. Nef'̂̂ şairlikte Urfî, Enverî ve Hakanî’ den aşağı kalmadığını ve kendisinin de Urfî-i Rûm olarak anıldığını söyler:

İktizâ etdi biraz yâve anunçün neyleyim

Yohsa dâ'im böyledir bana hitâb-i rüzgâr

Urfî-i Rûm Enverî-i asr u Hâkânî-i ahd

Feyzî-i mu'ciz-dem-i vahy-iktisâb-1 rüzgâr (K. 17/30-31) 
Yine 17. yüzyılın büyük şairlerinden Mezâkî de bu büyük şairlerin tamamının kendisinin şiirlerini görmüş olsalardı onu öveceklerinden bahseder:

Tâlib ü Urfî degül Enverî vü Hâkânî

Görseler nazmumı tahsîn idelerdi her-bâr (K. 10/63)

Zaman zaman kendisine övünmekten kaçınması gerektiği ile ilgili ögütler verse de Mezâkî tıpkı Nef'î gibi övmeyi ve övünmeyi seven bir şairdir:

Kim söyleşür Mezâkî-i muciz-kelâm ile

Her beyti bir gazel gazeli bir kasidedür (G. 116/9)

Şairin üslubunu muciz-kelâm olarak tanımlamasında nazmını, sözünü, kendisini fahr ederken muciz-beyân, mucize-gûy olarak tanımlayan Nef'ર̂'nin tesiri olduğunu düşündürtmektedir.

Tûti-i mucize-gûyem ne desem lâf değil

Çarh ile söyleşemem âyinesi sâf değil (G. 81/1)

Nefî-i muciz beyânım bende-i Mollâyı Rûm

Ne Hakîm-i Gaznevî’yim ne Emîr-i Dehlevî (K. 2/13)

Hem kasîde hem gazel bir tâze vâdîdir bu kim

İhtırâ-1 nâme-i muciz beyânımdır benim (K. 12/40)

18. yüzyılın ve Sebk-i Hindî’nin en büyük şairlerinden olan Şeyh Galip de aynı amacın yani daha önce söylenmemiş olanın peşindedir:

Dâ'imâ fikr-i dehân-1 dil-rubâdır pişemiz

Ma'ni-i nâ-güfteye dil-dâdedir endişemiz (G. 113/1)

Divan şiirinde yenilik yapmak isteyen ya da yaptı̆̆ı savında bulunan her şair gibi Şeyh Galip' in manzumelerinde "nev-zemîn, ma'nî-i nâ-güfte vb." ifadeleri s1k s1k yer alır (Yüksel, 1980; 98).

Yukarıda divanından örnek verilen şair, Hüsn ü Aşk adlı mesnevisinde övünme işine, Fahriyye-i şâirâne adlı bir başlık açmış ve bu bölümü, söz sultanının kendisi olduğu, kendisinden başka bir şairden eser görülmediği anlamına gelen Farsça şu beyitle tamamlamıştır:

"İn dem ki zi şâiri eser nist

Sultân-1 sühan menem diğer nist"

\section{Şeyhülislâm Yahyâ Divanında Fahriye Örnekleri}

\section{Şiirinin çeşitli nesnelere benzemesi bağlamında fahriye}

Divan şairleri şiirleriyle övünmek istediklerinde şiirlerini çeşitli unsurlara benzetir ve onlarla mukayese ederler. $\mathrm{Bu}$ unsurlar genellikle maddi olarak kıymetli olan inci, cevher gibi metalar olmakla birlikte; ab-1 hayat, y1ldızlar gibi farklı kıymetli unsurlar da olabilmektedir.

Şair, şiirini süslemek için nazım ipine nice yeni inciler getirdiğini söyler:

Arûs-1 nazmunı Yahyâ müzeyyen itmek içün 
Getürdi rişte-i nazmıyla niçe lü’lü-i ter (K.3/23)

Güzel söz söyleme ipi üzerine inci ve mücevher dizersen, dünya bahçesinin düzenine, tertibine benzer mi? diyerek soru soran Şeyhülislâm Yahyâ sözlerini inci ve mücevhere benzetmektedir:

Silk-i belâgat üzre dürr ü güher dizersen

Yahyâ nazîr olur mı nazm-1 cihân-sitâne (G.317/5)

Şair, hayat veren, can bağışlayan söz söyleme yeteneğinin herkese verilmeyeceğinin söyler ve bunu ölümsüzlük suyunu bulmak için Hızır'ın yardımına ihtiyaç duyulmasına benzetir:

Herkese nutk-1 revân-bahş virilmez Yahyâ

Himmet-i Hizr gerek kim buluna (G.26/5)

Şairin şiirini Hızır ve âb-1 hayât mazmunları ile zikrettiği bir diğer beyiti şudur:

Çeşme-i hayvânun agzı suyın akıtsun sözün

Hızr işitsün anı Yahyâ her zamân reşk eylesün (G. 284/5)

Yahyâ kendi gönül denizi coşmasaydı böyle ender incilerden bu denli çok bulunamayacağını söyler:

Çıkmazdı bu denli dür-i nâ-yâb kenâra

Yahyâ'nun eger bahr-i dili eylemese cûş (G. 163/5) sağlamıştır:

Şiirin kenarına inciler dizdiğini söyleyen şair, böylece belagat denizinin coşup taşmasını

Kenâr-1 nazma dürler dizdi Yahyâ

Belâgat bahrinün cûş u hurûşı (G. 439/5)

Şairin şiirini inciye benzettiği diğer beyitler şunlardır:

Feyz-i nîsân-1 `atâdur nola Yahyâ dişeler

Pâk ma`nâya dür ü nazm-1 dürer-bâra sadef (G. 171/5)

Gûşvâr itmezse dürr-i nazmunı Yahyâ o şâh

Kadr u kıymet bulmaya âlemde mânend-i hazef (G. 172/5)

Şi rr-i Yahyâ nev-arûs-1 medhüne ziynet virür

Meyl idersen nazm-1 lü'lü intizâma yaşarur (G.131/5)

Feyz-i nîsân-1 `atâdur nola Yahyâ dişeler

Pâk ma`nâya dür ü nazm-1 dürer-bâra sadef (G. 171/5)

Gûşvâr itmezse dürr-i nazmunı Yahyâ o şâh 
Kadr u kıymet bulmaya âlemde mânend-i hazef (G. 172/5)

Le âl-i nazmını kim görse dir ol bahr-i irfânun

Ne mümkindür ola mânendi deryâ dür-nisâr olsa (G.361/6)

Şair, sevgilisini tarif ederken, şiirinin bu bağın taze gülü olduğunu ve yerinin de yıldızların zirvesi olduğunu söyler:

Şi rüm ki oldı tâze güli bâg-1 vasfınun

Lâyıkdur olsa câygehi fark-1 Ferkadân (K./21)

Yıldız mazmununu kullandığı bir diğer beytinde şair, Şi’ra yıldızına parlaklığını veren şeyin kendi şiirinin olduğunu, gökyüzündeki diğer yıldızların da bundan dolayı kendisini kıskandığını düşünmektedir.

Biz o Cem `üz şi’rimüz şi râya feyz-i nûr ider

Reşk ider Yahyâ felekde encüm-i rahşân bize (G. 326/5)

Hocanın şehirde inci araması gibi şiir ehli olanlar yani bu işten anlayanlar, mecmualarda Yahyâ'nın şiirini aramaktadırlar:

Mecmû`alarda și ’üm arar ehl-i tab`olan

Hâce gibi ki şehrde 1kd-1 le âl arar (G. 132/3)

Şair şiirini saf bir aynaya benzetir, bu öyle bir aynadır ki söz ustası olan papağana bile söz söyleme işini öğretir:

Pâdişâhum nazm-1 Yahyâ saf bir âyînedür

Tûtî-i tab '-1 suhan-dâna suhan-âmûz olur (G. 133/5)

Şiirinin dervişane verilen bir va'za benzeten şair, görenlerin hepsi tarafindan beğenildiğini söyler:

Virdi Yahyâ'ya tevâzu 'la selâm ol şâh-1 hüsn

Hep pesend itdi gören bu vaz'-1 dervîşâneyi (G. 435/5)

\section{Şiirinin etkileyiciliği bağlamında fahriye}

Gönül bülbülü, gönül çeken bu matlayı duyduğunda o kadar beğenmiştir ki bin bir arzu ile hemen ezberine almıştır:

Bu beyt-i dil-keşi gûş eyleyince bülbül-i dil

Hezâr şevk ile itdi bu matla`ı ezber (K.3/15)

Şair, aşağıdaki beyitte "Baharı tarif ederken sözünü sabah rüzgârına, ırmağı tarif ederken sözünün akarsuya benzediğini söylemiştir. Nesim-i seher ve akarsu sözcükleri şairin şiirinin (sözünün) benzetildiği unsurlar olarak dikkat çekmektedir. Latif olması bakımından sabah rüzgârına teşbih olunan sözcük; akıcılık bakımından akarsuya benzetmiştir:

Sözüm nesîm-i seherdür bahâr vasfinda

Akarsudur suhanum cûybâr vasfinda 
Gönül ateşinden çıkan sözler elbette yakıcı olur. Bu yüzden Yahyâ'nın sözleri de adeta ateş parçasıdır yani yakıcıdır:

Suhan kim âteş-i dilden kopa lâ-büd olur pür-sûz

Anunçün her sözi Yahyâ'nun âteş-pâredür gûyâ olmasidir:

$\mathrm{Bu}$ kadar yakıcı olmasının bir diğer sebebi ise ayrılık ateşi ile yanmış gönlünde yara

Sözleri Yahyâ'nun olmazdı bu resme sûznâk

Nâr-1 hicrân ile yanmış dilde dâg1 olmasa (G. 320/5)

Şairin nazenin sevgilisi Yahyâ'nın şiirini, kendi can bağışlayıcı dudakları gibi rengin ve şirin olmasa ağzına almayacağını söyler:

Şi rün o yâr-i nâzenîn almazdı Yahyâ agzına

La '1-i revân-bahşı gibi rengîn ü şî̂ñ olmasa (G. 318/5)

Bir diğer beyitinde Yahyâ, "şiirini bir gülistan edasıyla tavsif ederek gül bahçesinin bütün güzelliklerini şiirinde birleştirip bu güzelliklerle bir göz ziyafeti sunan Yahyâ, bu ziyafetin ardından bir de tatlı ikram ederek şiirinin damaklardaki tadının doyumsuz olduğunu dile getirir"(Erkal, 2009; 227)

Her kang1 gülsitânda bir çeşme varsa Yahyâ

Agzı suyın bu şi r-i lezzet-şi’âr akıtdı (G. 389/6)

\section{Şiirinin orijinalliği, benzersizliği bağlamında fahriye} söyler:

Yahya şiir söyleme üstadı olduğunu ve söylediklerinin benzerini kimsenin işitmediğini

Üstâddur ki kimse nazîrin işitmemiş

Yahyâ bu fende kim ola üstâd-1 `andelîb (G-17/5)

Bir diğer kasidesinde, şiirinin mutluluk bağışladığını, gönle ferahlık verdiğini; şairinin ise güzel söz söyleyen, muhteşem ve tek olduğunu söyler:

Ne hoș dimiş bu safâ-bahş dil-küşâ nazmı

Yegâne muhteşem ol şầir-i suhan-perver (K.3/19)

Şeyhülislâm Yahyâ, sözlerinin daima aşkın sırlarını barındırdı̆̆ını söyler. Sözlerini bu sırları barındırması bakımından o kadar kıymetli görür ki dostlarından bunları yani sözlerini yabancılarla paylaşmamasını ister:

Yahyâ'nun olup sözleri hep sirr-1 mahabbet

Yârân işidüp söyleme yâbâne disünler (G.92/5)

Bu beyitte kendisine seslenen şair, kendisini marifet ağacına, şiirlerini de bu ağacın taze meyvelerine benzetildiğini, bunu da, bu yeni tarzı görenlerin söylediğini belirtir.

Hep görenler didi bu tarz-1 nevi ey Yahyâ

Ma'rifet nahli virüpdür yine bâr-1 tâze (G. 308/5)

Gerçek şudur ki, şair şiirini çok beğenmiştir. O kadar ki benzersiz bulmaktadır. İstanbul'un irfan ehli tarafından da beğenilmeye layıktır: 
Bu şi’rün hak budur Yahyâ ki gâyet bî-nazîr oldı

Pesend eylerse lâyık ehl-i irfânı Sitanbul'un (G. 195/5)

Şair, şiirinin hüner güneşinin en başı olduğunu, bu bakımdan daima Ahmed Şâh övgüsü yapmaya layık olduğunu belirtir:

Matla'-1 şems-i hünerdür nazmum ey Yahyâ benüm

Dâ'ima şi rümde Ahmed Şâhum ansam nola ben (G. 298/5)

Nice benzer bu hazef-pâreleri Yahyâ'nun

Dür-i pâkîze-i nazm-1 şeh-i `âlî-şâna (G. 341/5)

\section{Şairin şiir söylemede üstat olması bağlamında fahriye} söyler:

Yahya şiir söyleme üstadı olduğunu ve söylediklerinin benzerini kimsenin işitmediğini

Üstâddur ki kimse nazîrin işitmemiş

Yahyâ bu fende kim ola üstâd-1 `andelîb (G-17/5)

Şeyhülislâm Yahyâ, güzel şiir söylemeyi öğrenmek isteyenlerin kendi sözünü dinlemesi gerektiğini tembihler çünkü kendisini bu tarzın üstadı olarak görmektedir:

Eger pâkîze-gûlık tarzını ögrenmek istersen

Işit cân ile Yahyâ'nun sözin üstâddan kaçma (G.334/5)

Erbab-1 nazm olanların yani şairlerin daha önce söylenmemiş olanların peşinden koşmadıklarını anlayamadığını belirten şair, bunu kendisi gibi söz söylemeyi öğreten bir üstadın olmamasına bağlar:

Niçün ebkâr-1 ma'âni beslemez erbâb-1 nazm

Yohsa Yahyâ gibi üstâd-1 suhan-perver mi yok (G. 180/5)

Yahyâ'nın sevgilinin dudağını tarif etmesine şaşılmamalıdır. Zira o tatlı adalı bir papağan olarak bunu layıkıyla yapabileceğine inanır:

Yahyâ nola vasf-1 la' lin itsem

Bir tûtî-i sükkerîn-edâyum (G. 244/5)

Şair, şiirlerinin diğer şairlerinkine benzemediğini, sözlerinde hayat olduğunu söyler. Sanki Yahyâ'nın yaradılışına gaipten sırlar ilham olunmuş gibidir:

Benzemez eş âr-1 gayre sözleründe rûh var

Sırr-1 gaybî tab una Yahyâ senün mülhem gibi (G. 407/5)

Güzel şiir söylemek de şair iddialıdır hatta bu yolun padişahı olacağını ileri sürer ve yine kendisini sözünün eri olduğu için tebrik eder. Şair, iddiası ispat etmiş, güzel şiir söyleme yolunda sultan olmuştur:

Şi`r-i şirinünde hüsrevlikler itdün hak bu kim

Aferînler sana Yahyâ sözünün oldun eri (G. 411/5) 


\section{Şiirinin başkaları tarafından da beğenilmesi bağlamında fahriye}

Şeyhülislâm Yahyâ, redif olarak da Haleb'i kullandığg ve bu şehri övdüğü gazelinde son beyti kendisine ayırmıştır. Halebin vasıflarının anlatıldığı şiiri İran'ın büyük şairi Vassâf bile görse, gerçekten güzel bir şiiri olduğu hususunda hakkını teslim ederdi.

Yahyâ ide Vassâf dahı tab una insâf

Hoş şi`r didün hak bu ki evsâf-1 Haleb'de (G. 379/5)

Şiir ehli olanların yani bu işten anlayan şairlerin mecmualarda kendi şiirini aradıklarını söylemektedir.

Mecmû`alarda şi rüm arar ehl-i tab`olan

Hâce gibi ki şehrde 1kd-1 le âl arar (G.132/3)

Bütün herkesin beğenip övdüğü şiirinin Allah katında da makbul olmasını istemektedir, şair.

Hak yanında kabûl ola Yahyâ

Halk-1 ’âlem çün eyledi tahsîn (T. 2/8)

\section{Şiiri ile ilgili uyarı bağlamında fahriye}

Gönül çeşmesinde keder olmasaydı daha güzel şiirler yazabileceğini iddia eder:

Dahı latîf olurdı zülâl-i şi r-i terüm

Eger ki çeşme-i hâtırda olmayaydı keder (K.3/24)

Şiirinin yüksek sesle okunması gerektiğini söyler ki yanık sözlerin saz ile okunması hoş olur:

Okı nazm-1 Yahyầyı âvâz ile

Ki pür sûz söz hoş gelür sâz ile (S-76)

Melekler nağmesini işitmelidir. Aynı nağmeyi duyan felek de bu sözlerin etkileyiciliği ile şevke gelip sema edecektir:

Melek nagmeni istimâ eylesün

Felek şevke gelsün semâ eylesün (S-77)

Şeyhülislâm Yahyâ, sözlerinin daima aşkın sırlarını barındırdığını söyler. Sözlerini bu sırları barındırması bakımından o kadar kıymetli görür ki dostlarından bunları yani sözlerini yabancılarla paylaşmamasını ister.

Yahyâ'nun olup sözleri hep sırr-1 mahabbet

Yârân işidüp söyleme yâbâne disünler (G.92/5)

Gazelde ol mehi Yahyâ lebiyle vasf itsün

Şekerle beslesün ol tûtî-i suhan-dânı (G. 431/5)

Marifet incisinin denizi olan sözleri kulağına küpe olmayanlar şairi hakkıyla bilemezler.

Şimdi ey Yahyâ benüm bahr-i le'âl-i ma'rifet

Sözlerüm gûşında mengûş olmayan bilmez beni (G. 446/5) 


\section{Şairliği ve şiiri dışında fahriye yapılan beyitler}

Sadece bir canı olan şair sevgilisi yolunda sanki bin canı varmış gibi saçmaktadır. Yahya dostları arasında da kendisi gibi cömert birisinin olmadığını bilmektedir:

Mâ-melek bir cânı var bin cân ile eyler nisâr

Şimdi yârân içre Yahyâ gibi bir cömerd yok (G. 187/3)

Şair aşk dersinin izanında üstat olduğunu, konuyu açıklayabilecek, işlenmemiş bir şey kamış $\mathrm{m} ı$ bilebilecek tek kişinin kendisi olduğunu söyler. Aşk dersinde işlenmedik bir konu kalmış mı bunu bilse bilse Yahyâ bilir ve açıklayabilecek tek kişi de kendisidir:

Şerh iderse ders-i aşkı yine Yahyâ şerh ider

Bir mahall kalmış mıdur zîrâ bu fende görmedük (G. 201/5)

Sevgili Yahyâ'dan başkasına vefa göstermemelidir. Zira o sevgili ne kadar cefa gösterse ona da razıdır ve bu bakımdan kendisini, sevgilinin vefasını tek hak eden olarak görür:

Yahyâ'dan özge kimseye tek eyleme vefâ

Kâ'ildür ol ne denlü olursa cefâlarun (G. 204/5)

Sevgili güzeldir, padişahtır ve ona sadık âşık olacak kimseler de çoktur; ancak dikkatle bakarsa hakikatte hiçbirisi şaire denk değildir:

Güzelsin sana şâhum âşık-1 sâdık geçer çokdur

Bakarsan hakk ile Yahyâ gibi yokdur hakîkatde (G. 345/5)

\section{Şeyhülislâm Yahyâ Divanında Tevazu Örnekleri}

Buraya kadar kısaca fahriyeye, nerelerde görüldüğüne, şairlerin neden fahriye yapmaya ihtiyaç duyduklarına ve bilinen meşhur örneklerine yer verilmiştir. Şairler fahriye yapmaktan hoşlandıkları hatta ihtiyaç duydukları bir gerçek olsa da tam tersi durumlar da söz konusudur. Tevazu gösterdikleri, kendilerine tevazu telkin ettikleri, kendilerini olduklarından aşağı gösterdikleri beyitler de mevcuttur. Fahriyelerde övgü konusu genellikle şiir, şairlik, kalem üzerineyken tevazuda genelde alçak gönüllü olmanın yönü âşıklık hususundadır. Âşıklık konusu, hem beşeri hem de uhrevi aşk1 ihtiva etmektedir. Beşeri aşkta maşukuna karşı alçakgönüllü olan şair, uhrevi aşkta da bu makama koyduğu kişiye göre aynı durumdadır. Şair, maşuk makamında tasavvur ettiği Allah, peygamber ya da şeyhi kim ise ona karşı daima tevazu konumundadır. Ancak şairlerin kendilerine ya da başkalarına âşıklık konusunun dışında da tevazu sahibi olmayı öğütledikleri beyitlere rastlanmaktadır. Hazînî aşağıdaki beyitte ilim ehlinin yani ilim sahiplerinin daima mütevazı olması gerektiğini söyler:

Ehl-i 'ilm olur tevâzu'da müdâm

Virdi anlaruñ cevâbını tamâm (Hazînî) (Avcı 2007: 104)

Evini yıktıran Çorlulu Ali Paşa'ya sitemle söylediği ve çok beğenilen beytinde Nâbî, mevki sahibi olanların bu duyguyla sarhoş olup çok mağrur olmaması gerektiğini, çünkü sarhoşluk geçince yani makam, mevki elden gidince kişiye yalızca baş ağrısı kalacağını söylemiştir:

Çok da mağrûr olma kim meyhâne-i ikbâlde

Biz hezârân mest-i mağrûrun humârın görmüşüz (Nâbî, G. 319/2)

Örneklerde görüldüğü gibi, farklı konularda da tevazu sahibi olmayı öğütleyen beyitler olsa da şairlerin en mütevazı oldukları yer sevgililerin karşısıdır. Şairin daimi âşık makamında olduğu Divan şiirinde, maşuk şah, padişah, sultandır. Bu durum onu ulaşılmaz yaptığı gibi, onunla ilgili tüm 
unsurları da âlî yapar; şairi ve şairle ilgili unsurları da bir o kadar hakir yapar. Sevgiliyi en uç noktalarda tasvir eden şair ise kendisini sıradanlaştırır hatta alçaltır.

Maşuk kavramının gerçek bir sevgili gibi algılanabileceği Divan şiirinde, şairinin bakış açısına göre Allah'1, peygamberi, bir şeyhi ya da devlet adamını da karşılayabilir. Maşuk hangi pozisyonda olursa olsun âşığa yani şaire düşen de en üstlerde tasvir edip kabullendiği sevgili profiline karşı haddini bilmektir. Dolayısıyla Divan şiiri geleneğinde fahriye beyitleri kadar, hatta daha fazla tevazu anlamı içeren beyitler de vardır.

Hayâlî̀ye ait beyitte şair, sevgilisinin kapısının eşiğinde toprak olmak istemektedir; ancak bunun bile haddinin aşmak olduğunu düşünür:

Âsitân-1 yârda kendin türâb ister gönül

Haddini bilmez özün 'âlî-cenâb ister gönül (H. G.315-1)

Divan şiirinde sevilenin ulaşılmaz olması onu yüceltirken şairi alçaltmaktadır. Zaten kul, köle, dilenci olan şair sevgilisinin ayakları altında olmaya, bastığı yerlerin toprağı olmaya, hatta kapısındaki köpeklerle yemek yemeyi padişahlarla yemekten üstün görmektedir.

Eşigi itleriyle hem-sifâl oldum bihamdillâh

Bu zevki bulmadım şehlerle gerçi Câm-1 Cem çektim (H.210/G.347-3)

Yukarıda bazı örnekleri verilen fahriye ya da tevazuyu öğütleyen beyitlere hemen her şairin divanında rastlanabilir. Bununla birlikte çalışmanın konusu Şeyhülislâm Yahyâ divanında bulunan fahriye ve tevazu örnekleridir. Şeyhülislâm Yahyâ divanında bu tarz beyitlerin örneklerine kasidelerinde, divanının başında yer alan sâki-nâme türündeki mesnevisinde, gazellerinde ve tarihlerinde rastlanır. Örnek beyitlerin tespiti için Hasan KAVRUK'un hazırladığı Şeyhülislâm Yahyâ Divanı Tenkitli Metin adlı eserden faydalanılmıştır.

Çalışmaya konu olun şairin divanı tetkik edildiğinde, şairin, gerek fahriye yaptığı gerekse tevazu gösterdiği beyitlerde bazı anlatım birliktelikleri tespit edilmiştir. Bunlar fahriye kısmında, şairin şiirini benzettiği unsurlar, şiirinin etkileyici olması, orijinal yani benzersiz olması, söz söyleme sahasında üstat olması gibi benzer anlam ihtiva eden çeşitli beyitlerdir. Bunun dışında şairin şiirleriyle hem fahriye yapıp hem de okuyucuyu uyardığg beyitlere rastlanmış ve ilgili beyitler bir arada değerlendirilmiştir.

16. yüzyılın sonu ile 17. yüzyılın başlarında yaşayan şair, kadılık, müderrislik gibi önemli devlet görevlerinde bulunmuş, şeyhülislâmlığa kadar yükselmiş bilgin bir şahsiyettir. Şairliği gerek zamanında gerekse kendisinden sonraki asırlarda beğenilip takdir edilmiştir. Zaman zaman kendisine mütevazı olmayı öğütlese de şairin kendisiyle övündüğü beyitler açık ara daha fazladır. Şairin tevazuyu öğütlediği beyitleri anlamları bakımından sınıflandırılacak olursa sevgilinin karşısındaki durumu bakımından, memduhunun karşısındaki durumu bakımından ve genel olarak tevazuyu öğütleyen beyitler şeklinde adlandırılabilir.

\section{Âşı̆̆ın karşısındaki durumundan dolayı tevazuyu öğütlediği beyitler}

Şair sevgilisi için yanmaya yakılmaya razıdır; ama buna imkân verecek bir meclis bulunmamaktadır. Şair, böyle bir meclis olursa sevdiğinden kendisine iltifat edip onu mum eylemesini ister.

Meclis olmaz kim o şâh içün yanup yakılmaya

Iltifât idüp nola Yahyâ'yı eylerse cerâg (G. 170/5)

Şair, şah olarak gördüğü sevgilinden özür dilemelidir. Çünkü aşkın nihayetsiz dertleri aşığın tamam olmasını sağlayacaktır. Şair, mevcut haliyle kendisini noksan ve ham olarak görmektedir. 
Hemân o şâhdan eksükligün dile Yahyâ

Tamâm ider seni de derd-i bî-nihâye-i ’aşk (G. 182/5)

Şair, sevgilisinin vuslatına ulaşmasını imkânsız görmektedir. Çünkü sevgiliye kavuşmasını sağlayabilecek altın ve gümüşü yoktur. Bu durum ağlamaktan gözlerinden kanlar aksa hatta o kanlar sevgilinin aşkından sararmış yüzünü boyasa da durum değişmeyecektir.

$\mathrm{Al}$ olsa yaşun kana boyansa ruh-1 zerdün

Ümmîd-i visâl eyleme çün sîm ü zerün yok (G. 186/2)

İnsan bir deniz olsa bile tıpkı bir zerre gibi kendisini aciz görmeli, göstermelidir. O gonca gibi sevgilinin gönlüne bir şebnem gibi girmenin yolu böyle olmaktan geçer.

Bahr isen de katre-i nâ-çîz göster kendini

Gönline gir ey gönül ol goncenün şeb-nem gibi (G. 407/2)

Şair, gönlünü anarak, kendisine seslenir ve bir sevgili yoksa kendisini yüce sanmasının anlamı olmadığını söyler. Sevgilisi olmayan birisi câm-1 atlas (gökyüzünün en üst bölümü) olsa da bir şey değişmez çünkü onun da bir yıldızı yoktur:

Özün ey dil yukardan sanma çün bir mâh-pâren yok

Tutalum câm-1 atlas kendü olmuşsun sitâren yok (G.183/1)

\section{Memduhunun karşısındaki durumundan dolayı tevazuyu öğütlediği beyitler}

Sultan Murad övgüsü amacıyla kaleme alının müzeyyel gazelde şair ona layık bir şiir söylemenin mümkün olmadığını söyler.

Yahyâ ne mümkin bir şi`r dimek

Sultân-1 âlî-mikdâra lâyık (184/5)

Şairin Sultan Murad övgüsü için yazdığı müzeyyel gazelinde nice ince manalar hayal etmek istediğini amma onun gibi nazik-edalı bir söyleyişe sahip olamayacağını belirtir:

Nice pâkîze ma nâlar hayâl itmek olur ammâ

Nice mümkin şeh-i devrân gibi nâzük-edâ itmek (G. 202/7)

\section{Genel olarak kendisine tevazuyu öğütlediği beyitler}

Şair, kendisine namsız, nişansız olmak gerektiğinin öğütlerken asıl mahlasın dünyada bu olduğunu söyler. Kendi şiirlerinin tanınması amaçlı kullanılan mahlas beyti aynı zamanda şairden kalan bir iz bir işarettir. Şair bu beyitte bu izden işaretten vazgeçmesi gerektiğini çünkü doğru olanın bu olduğunu kendine öğütler:

Hemân dünyâda bî-nâm ü nişân ol

Budur dünyâda Yahyâ sana mahlas (G. 165/5)

Dünya endişesinden kendisini Yahya gibi soyutlayan âşık (bu beyitte şair kendisinden başka bir âşıktan bahsetmektedir), aslında namsız ve nişansız olarak bir ad bırakır. Şair yukarıdaki bir diğer beytindeki gibi aşığa isimsiz, şöhretsiz olmayı ve dünyalık endişelerden kendisini uzak tutmasını ögütler.

Idüp Yahyâ gibi kayd-1 cihândan kendisin âzâd 
Olup âlemde bî-nâm u nişân bir ad ider âşık (G. 185/5)

\section{Kendisine yönelik hem övgü hem de tevazu anlamı bulunun beyitler}

Şeyhülislâm Yahyâ divanı fahriye ve tevazu beyitleri açısından tetkik edilirken sayıları çok az da olsa bazı beyitlerde hem övünme anlamı hem de alçak gönüllü ifadelerin birlikte kullanıldığına rastlanmıştır.

Şair, kendisini tecrit ederek gönlüne seslendiği beytinde, gönlünün kendisi gibi alçak gönüllü olamadığı için sevgilinin ayağının öpmeye vasıl olamadığından dert yanar. Kendisini alçak gönüllü bulan şair bunanla övünürken kendisi gibi olamayan gönlünden de şikâyet eder.

O1 şâh-1 hüsnün iremedün pây-bûsına

Yahyâ gibi ki hâk-nihâd olmadun gönül (G. 216/5)

Sevgilinin kölesi olduğunu söyleyerek bir miktar tevazu gösteren şair; sevgilisinin kendisi gibi bir kölesi olduğu için kıymetini bilmesi gerektiğini hatırlatarak da fahriye yapar. Ey gönül götüren sevgili diyerek, ona kendi hatırını, gönlünü kırmamasını, eleştirmemesini tembihler. Bilakis kıymetini bilmeli, ona iltifat etmelidir; çünkü gönlünün Yahyâ gibi bir kölesi bulunmaktadır.

Iltifât it dil-berâ dünyâya virme hâtırun

Kıymetin bil çünki Yahyâ gibi var bir çâkerün (G. 196/5)

Benzer bir anlam şairin aşağıdaki beytinde de mevcuttur. Şair her köşede şiirlerinin okunmasıyla övünür; ancak bunu da kendisine bunları söyleten saçın sahibi olan sevgiliye borçlu olduğunu ekleyerek de tevazu gösterir:

Her gûşede nazmun okınur var ise Yahyâ

Söyletdi o kâkül sana eş âr-1 perîşân (G. 273/5)

Gonca ağızlı sevgilisinin sözlerini aklında tuttuğunu söyleyen şair sevdiğini suhan-1 hûb (tatlı dilli) olarak nitelendirir. Burada tatlı dilli olanın sevgilisi olduğunu söyleyerek tevazu gösterir durumdadır; ancak bu sözleri unutmamasını da kendisinin söz söyleme ehli olmasına bağlar:

Yâdımdadur ol gonce-femün sözleri Yahyâ

Tab` ehli ider mi suhan-hûbı ferâmûş (G. 157/5)

\section{Sonuç}

Yüzy1llar boyunca süren Divan şiiri geleneğinde, fahriye, hemen hemen bütün şairlerin, şiirlerinde başvurdukları ortak unsurlardan birisi olmuştur. Şairin kendi kendisiyle övünmesi anlamına gelen fahriye, şairler tarafından o kadar çok kullanılmıştır ki kaside nazım şeklinde bir bölümün de adı olmuştur. Fahriye denilince akla kaside gelse de şairlerin fahriye yapmaya imkân buldukları her yerde fahriye yaptıkları görülmüştür. Kendileri ile övünmeyi seven Divan şairleri yine geleneğin bir özelliği olarak belli kavramlar etrafında fahriye yapmışlardır. Nazmı, nesri, sözü, kalemi şairin kendisiyle övündüğü genel vasıflardır ki sıradan bir insanın kendisiyle övünmesinden farklıdır. Şair, fahriye yaparken de gelenekte çok tanınmış ve üstat olarak kabul edilen şairlerle kendilerini kıyaslarlar. Bu kıyaslamada, şair kendisini çağdaşı olan şairlerden hatta kendisinden önceki şairlerden üstün tutar.

Buldukları her firsatta fahriye yapmaktan geri kalmayan Divan şairi, dikkat çekici bir şekilde tevazu göstermekten de kaçınmaz. Ancak, şairin tevazu gösterdiği manzumeler genellikle tevhit, münacat gibi dini muhtevalı olanlarda Tanrı karşısındaki konumu ya da kaside yazdığı devlet büyüğü karşısındaki konumu ile ilgilidir. Bunların dışında ise yine geleneğin bir özelliği olarak sevdiğinin karşısında da son derece mütevazıdır. Şair, maşukun karşısında kendini küçük görmekten, aşk 
dilenmekten asla imtina etmez; çünkü bu durum onun aşkının ne derece büyük olduğunu ispatlamaktadır. Yine maşukun vuslatına yol bulunamayan; aşığa yani şaire kolay kolay yüz vermeyen; şairden başka seveni, cevr ü cefası çok bir mahbup olması, şairi mütevazı olmaya iten sebeplerdendir.

Divan şiirinin kuralları, yapısı, dili, ortak mazmunları ve aynı söz sanatları, şairler tarafından yüzyıllardır kullanılması bu edebi geleneğe yöneltilen en büyük eleştirilerden birisidir. $\mathrm{Bu}$ eleştirilerin büyük bir kısmı Divan edebiyatı geleneğinin ömrünü tamamlanmasından sonra gerçekleşmiştir. Bununla birlikte özellikle 16. yüzyıldan sonra şairler de farklı şeyler söyleme ihtiyacı hissetmişler ve orijinal anlamların peşine düşmüşlerdir. Nazım şekli, vezni ya da sanatlarda çok büyük değişikliklere gidemeyen gelenek şairi, farklılığını anlamla ortaya koymaya çalışmıştır.

Anlamda orijinalliği arayan, bulan ve bununla iftihar eden şairlerden birisi de Şeyhülislâm Yahyâ'dır. Genellikle kasidelerde olduğu düşünülen fahriyelerin, Şeyhülislâm Yahyâ'da, kasidelerde de olmakla birlikte şairin divanının tamamına yayıldığı görülmektedir. Kasidelerdeki fahriye beyitlerinin, bir bölüm şeklinde yani art arda gelmediği ve kasidenin içinde dağınık bir şekilde kullanıldığı görülmüştür.

Şair, diğer şairlerde olduğu gibi şiirleriyle övünürken benzer ifadeler kullanmıştır. Şiirini tanımlamak için kullandığı övgü ifadeleri şi r-i ter, sırr-1 mahabbet, nazîrin işitilmemiş, safâ-bahş, dil-küşâ, tâze gül, dürr, güher, lü'lü, dil-keş, nev-ârus, nesîm-i seher, akarsu, âteş-pâre'dir. Kendi şairliğini tanımlarken yegâne, muhteşem, pâkîze-gû, üstâd, üstâd-ı 'andelîb, suhan-perver gibi ifadelere yer vermiştir.

Şairin, fahriye konusunun genellikle şiiri ve şairliği bağlamında olduğu tespit edilmekle birlikte, bir diğer övünme konusu ise âşıklık iddiasıdır. Bu da yine Divan geleneğinin bir özelliği olarak karşımıza çıkmaktadır. Şair, âşıklık hususunda rakipsizliği ve bu fende bütün ilimleri tahsil etmesi ile övünür. Fahriye yaptığı beyitlerden birinde de konunun cömertlik olduğu görülmüştür.

Şairin tevazu gösterdiği beyitlerle ilgili yapılabilecek ilk tespit, fahriye beyitlerine kıyasla sayıca çok daha az olmasıdır. Divanda şairin fahriye yaptığı beyit sayısı kırk dokuz iken, bu sayı mevzu tevazu olunca dokuz beyte düşmüştür. Şairin fahriye ve tevazu beyitlerinin dışında aynı beyitte hem fahriye yapıp hem tevazu gösterdiği beyitler vardır ki bunların da sayısı dörttür.

Bununla birlikte şairin fahriye yaptığı beyitler yedi farklı başlıkta ele alınabilirken, tevazuda bu sayı üç başlıkla sınırlı kalmıştır. Bu farka sebep olan unsurun ise tevazu beyitlerindeki örneklerin fahriye beyitlerine nispeten çok daha az olmasıdır.

Tevazu başlığında şair kendisine âşığının konumundan dolayı, memduhunun konumundan dolayı yani onların itibarda kendisinden çok üstün olduklarından dolayı tevazuyu öğütlemiştir. Bunların dışındaki birkaç tevazu beyti ise genel olarak adsız, ünvansız, nişansız olmak gerektiğini öğ̈̈tlemektedir.

Şeyhülislâm Yahyâ'nın divanı tetkik edilirken şairin gerek fahriye yaptığı gerekse tevazu gösterdiği beyitlerde Divan şiiri geleneğinin çok dışına çıkmadığı görülür. Şairin fahriye beyitleri de tevazu beyitleri de gelenekle aynı çizgidedir. Konu olarak bunların dışına çıkamayan şair ifade gücü açısından son derece yetkin ve orijinaldir. Geleneğin de şairden beklentisi tam anlamıyla budur. Tüm bunlardan yola çıarak 17. yüzyılın büyük şairi Şeyhülislâm Yahyâ'nın Divan şiirinin klasik mazmunlarının ve çerçevesinin dışına çıkmadan üslubu ile farklı olmayı başarabilmiş̧ şairlerden birisidir. 


\section{Kaynakça}

Akkuş, M. (1993). Nef'i Dîvânı, Ankara: Akçağ Yayınları.

Alparslan, A. (1988). Şeyh Galip, Ankara: Kültür ve Turizm Bakanlığı Yayınları.

Avcı, İ. (2007). Hazînînin Manzum Şerh-i Hadîs-i Erbaîn Tercümesi. (Yayımlanmamış Yüksek Lisans Tezi) Balıkesir Üniversitesi Sosyal Bilimler Enstitüsi.

Bilkan, A. F. (1997). Nâbî Divanı, İstanbul: MEB Yayınevi.

Dilçin, C. (2011). Divan Şiiri ve Şairleri Üzerine İncelemeler, İstanbul: Kabalcı Yayınevi.

Erkal, A. (2009). 17. Yüzyıl Divan Şiiri Poetikası. (Yayımlanmamış Doktora Tezi) Atatürk Üniversitesi Sosyal Bilimler Enstitüsü.

İsen, T.I. (2002). Divan Şiirinde Fahriye. (Yayımlanmamış Yüksek Lisans Tezi) Bilkent Üniversitesi Ekonomi ve Sosyal Bilimler Enstitüsü.

İsen-Durmuş, T.I. (2007). “Fahriyeler Işı̆̆ında Osmanlı Şiirinde İdeal Şairin Portresi”. Bilig, Güz, S. 43, s. 107-116.

Kavruk. H. Şeyhülislam Yahyâ Dîvânı. T. C. Kültür ve Turizm Bakanlığı Kütüphaneler ve Yayımlar Genel Müdürlüğü 3147 Kültür Eserleri 430 ISBN 978-975-17-3354-2

http://ekitap.kulturturizm.gov.tr/Eklenti/10655, seyhulislamyahyadivanihasankavrukpdf.pdf?0

Mermer, A. (1991). Mezâkî Hayatı, Edebî Kişiliği, ve Divanı'nın Tenkitli Metni. Ankara: Atatürk Kültür, Dil ve Tarih Yüksek Kurumu.

Okay, O- Ayan, H. (2006). Şeyh Galip Hüsn ü Aşk. İstanbul: Dergah Yayınları.

Tarlan, A. N. (1992). Hayâlî Divanı. Ankara: Akçağ Yayınları.

Yazar, İ-Uslu, E. (2016). “Kasidelerde Şair Algısı”. Uluslararası Sosyal Araştırmalar Dergisi, S. 43, c. 9, s. 487-504. https://doi.org/10.17719/jisr.20164317625

Yüksel, Ş. (1980). Şeyh Galip Eserlerinin Dil ve Sanat Değeri. Ankara: Türkiye İş Bankası Kültür Yayınları. 